\title{
An Economic Analysis of Kinnow Cultivation in Sirsa District of Haryana
}

\author{
Mousumi Priyadarshini ${ }^{*}$, K.K. Kundu ${ }^{2}$, Dalip Kumar Bishnoi ${ }^{2}$ and Nirmal Kumar ${ }^{3}$ \\ ${ }^{1}$ Division of Agril. Economics, IARI, New Delhi, India \\ ${ }^{2}$ Department of Agril. Economics, CCSHAU, Hisar, India \\ ${ }^{3}$ SNIATE, CCSHAU, Hisar, India \\ *Corresponding author
}

\section{A B S T R A C T}

Keywords

CAGR, NPV, IRR,

$\mathrm{B}: \mathrm{C}$ ratio, Payback period

Article Info

Accepted:

20 June 2020

Available Online:

10 July 2020
The study was based on both primary as well as secondary data. Primary data related to cost and returns of Kinnow cultivation were collected from Sirsa district of Haryana. Whereas, secondary data related to area, production and productivity of Kinnow were obtained from department of horticulture, government of Haryana. The CAGR in area, production and productivity of Kinnow in Haryana was found to be 11.69, 17.67 and 5.36 respectively. The NPV, IRR, B:C ration and payback period were estimated to be $₹ 747703.64,26.24 \%, 1: 3.79$ and 7 years respectively. Lack of infrastructure for processing, storage, lack of better marketing facility, postharvest management some of major constraints faced by Kinnow growers were identified in the study area.Keeping in view the high profitability and constraints, it can be suggested to the government to focus more on infrastructural facilities for post-harvest management, ensure availability of quality planting materials to the farmers and provide better marketing facility in the study so that more income of the farmers' can be ensured.

\section{Introduction}

Horticultural sector play a vital role in providing the livelihood security to the farmers under the changing agriculture scenario (Kumar et al., 2017). No doubt green revolution has increased the production of rice and wheat and ultimately farmer's income in Haryana but it has some adverse effects like monoculture, increase in electricity consumption etc. Due to rising per capita income, growing urbanization and globalization, there is a shift in the consumption patterns of both rich as well as poor households in favor of high value crops (Grover et al., 2012). With nature gifted suitable agro-climatic condition, Haryana has a large capacity in terms of production of 
fruits and vegetables. In Haryana citrus is the leading fruit crop among all the major fruits grown in Haryana. Kinnowisa hybrid of two citrus cultivars, namely, King (Citrus nobilis) and Willow leaf (Citrus deliciosa) mandarins originated at Riverside, California (Sharma et $a l ., 2007)$. Cultivation of Kinnow in Haryana gained momentum among the fruit growers as it has higher profitability and good market value relative to some of the other crops in the state. Keeping in mind all these facts, the study was conducted with specific objectives viz., Toanalyze the trends in area, production and productivity of Kinnow in Haryana, to calculate the costs, returns and economic feasibility of Kinnow and To identify the constraints faced by the Kinnow growers in Sirsa district of Haryana.

\section{Materials and Methods}

The study was undertaken in Sirsa district of Haryana. Further, thirty Kinnow growers were interviewed thought pretested interview schedule from the selected district randomly. Secondary data regarding area, production and productivity of Kinnow in Haryana were collected from Departments of Horticulture, Government of Haryana from 2005-06 to 2017-18. The CGR was then calculated to show the trends in area, production and productivity. The growth rates were estimated using exponential growth functional form as under:

$\mathrm{Y}=\mathrm{AB}^{\mathrm{t}} \mathrm{U}_{\mathrm{t}}$

Taking $\log$ i.e., $\log \mathrm{Y}=\log \mathrm{A}+\mathrm{t} \log \mathrm{B}+\log$ $\mathrm{U}_{\mathrm{t}}$

$$
\text { i.e. } y=a+b^{t}+u t
$$

Where, $\mathrm{Y}=$ area or production or yield,

$\mathrm{A}=$ constant,

$\mathrm{B}=$ regression coefficient,

$\mathrm{U}_{\mathrm{t}}=$ disturbance term And

$\mathrm{t}=$ time in years starting from the base year
2005-06.

The compound growth rate (Antilog of b-1)* 100 was used to calculate the growth rates in area, production and productivity of fruit crops at state levels for a period of 13 years.

\section{Cost and returns from Kinnow cultivation}

To analyse the economics of Kinnow cultivation, it is essential to study the cost in two parts viz., establishment costs and operational costs. For analysis of data, various economic tools like net present value (NPV), benefit cost ratio $(\mathrm{B}: \mathrm{C})$, internal rate of returns (IRR), paybackperiod were used.

\section{Depreciation and interest rate of Kinnow cultivation}

For estimating the annual cost, the depreciation has been worked out @ 4 per cent per annum of the fixed investment (i.e. establishment cost) by applying straight line method or direct method, assuming the productive life of Kinnow. Further rate the interest has been taken @ 12 per cent per annum on operational cost.

\section{Amortization of fixed cost}

The annual amortization of fixed cost was computed from the investment made on establishment of Kinnow, assuming the rate of interest 12 per cent per annum and the expected life 25 years for Kinnow. Thus, annual amortization was worked out by using the compounding cost formula.

$$
\begin{aligned}
& I=B \frac{i}{1-(1+i)^{-n}} \\
& \text { Where, } \\
& I=\text { Annual cost, } \\
& B=\text { Present fixed cost, }
\end{aligned}
$$


$\mathrm{i}=$ Interest rate $(12 \%$ per annum), and

$\mathrm{n}=$ Economic life of the orchard (in years).

\section{Economic viability}

To examine the economic feasibility of orchard while studying the economics of Kinnow cultivation, four indicators were used viz., net present value (NPV), internal rate of returns (IRR), cost benefit ratio and payback period. The detailed method used to find out these indicators are given below.

\section{Net present value}

Future net returns were discounted to their net present value by using the following formula:

N.P.V. =

$$
\begin{array}{cc}
\mathrm{R}_{1} & \mathrm{R}_{2} \\
\frac{\mathrm{R}_{\mathrm{n}-1}}{(1+\mathrm{r})^{1}}+\frac{\mathrm{Rn}}{(1+\mathrm{r})^{2}}+\ldots & +\frac{}{(1+\mathrm{r})^{\mathrm{n}-1}}+\frac{}{(1+\mathrm{r})^{\mathrm{n}}}
\end{array}
$$

Where, $\mathrm{R}_{1}, \mathrm{R}_{2} \ldots \ldots \mathrm{R}_{\mathrm{n}}$ are the net returns in the period $1,2, \ldots \ldots . \mathrm{n}$ respectively, ' $\mathrm{n}$ ' is the life span in years of the investment in the orchard, ' $r$ ' is the discount rate (prevailing interest rate) and N.P.V. is net present value of returns $R_{1}, R_{2}, R_{3} \ldots \ldots \ldots R_{n}$.

\section{Internal rate of returns}

In estimating the internal rate of return, the investment cost and incremental gross returns for each year in the life of orchard were calculated. The internal rate of returns were calculated at the different rate of discount until it satisfies the relationship $\mathrm{B}-\mathrm{C}=0$ where ' $B$ ' is the sum of discounted stream of positive value (returns) and ' $\mathrm{C}$ ' is taken as the sum of discounted stream of negative values (costs).



\section{Benefit cost ratio}

The benefit cost ratio is the ratio between the sum of discounted benefits of returns (R) and the sum of discounted cost $(K)$, i.e. $B=R / K$. If this ratio is greater than 1.00 then the investment in Kinnow orchard is considered to be economically viable.

\section{Payback period}

It is the period within which the cost of the orchard is fully recovered from its own returns. In other words, it indicates the number of years by which the returns(R) equal, to the cost of orchard (K). For this condition the following relationship must be satisfied.

$\sum_{i=1}^{n} \mathrm{Ri}=\mathrm{K}$

Where,

$\mathrm{i} \quad=1,2,3 \ldots \ldots \mathrm{n}$ year,

$\mathrm{R}=$ Indicates the return over a number of year,

$$
\mathrm{K}=\text { Indicate the cost of orchard. }
$$

\section{Identification of constraints}

Sixty farmers from the Sirsa district were surveyed with the pre tested schedules and their opinions were considered. For identifying the production and marketing constraints faced by the farmers Henry Garrett ranking technique was used. The respondents were asked to rank the given constraints. The order of merit thus given by the respondents was converted in to ranks using the following formula 
Percentage position $=\frac{100-\left(\mathrm{R}_{\mathrm{ij}}-0.5\right)}{\mathrm{N}_{\mathrm{j}}}$

Where,

$\mathrm{R}_{\mathrm{ij}}=$ Rank given for ith item $\mathrm{j}^{\text {th }}$ individual

$\mathrm{N}_{\mathrm{j}}=$ Number of items ranked by $j^{\text {th }}$ individual

\section{Results and Discussion}

\section{Compound growth rate in area, production} and productivity of Kinnow in Haryana

It is evident from the Table 1 that in the period (2005-2017) the area, production and productivity of Kinnow showed increase by $313.13, \quad 382.29$ and 16.86 per cent, respectively in the year 2017-18 over the area, production and productivity under Kinnow in the year 2005-06 in Haryana. The compound growth rate in area, production and productivity of Kinnow in Haryana were recorded as 11.69, 17.67 and 5.36 per cent, respectively. During the last 13 years the average area, production and productivity of Kinnow were 11.69 thousand hectares, 17.67 thousand tonnes and 5.36 tonnes per hectare, respectively. The area and production of Kinnow showed increasing trend over the time period 2005-18. However the productivity has not shown any specific trend.

\section{Economics of Kinnow orchard in Sirsa, Haryana}

Sirsa district shares 49.51 per cent of the total area under Kinnow cultivation in Haryana. Therefore 60 farmers from this district were randomly selected to analyse the economics of Kinnow orchard in Haryana.

\section{Establishment cost of Kinnow orchard in Haryana}

The per hectare average total establishment cost of Kinnow orchard in Sirsa district of
Haryana was found to be ₹ 122460 . The construction of pond $(35.59 \%)$, installation of drip irrigation (19.23\%), Permanent fencing $(10.24 \%)$, preparation of land and layout (5.71\%), cost of plants (5.19\%) cost of equipment $(4.80 \%)$, manures and fertilizers $(3.87 \%)$, transportation of plants $(3.80 \%)$ were found be major component of the average establishment cost of kinnow orchard. These results are in conformity with the findings of Gangwar et al., (2005) and Bhat et al., (2011) (Table 2).

\section{Operational cost of Kinnow orchard in Haryana}

Per hectare operational costs increased over the years due to higher expenses involved on various inputs, rise in cost of staking and watch and ward which may be attributed to the direct relationship between input requirements and age of the plant. It was clearly evident from the results that the per hectare average annual operational cost of Kinnow orchard ranges from ₹ 29376 in the first year to ₹ 75625 in the seventh year after seventh year it becomes more or less stabilised. The per hectare average annual operational cost from the first year to the seventh year were found to be ₹ 13091.57 on plant protection insecticides and pesticides $(23.10 \%)$, ₹ 7419.29 on intercultural operation and hoeing (13.09\%), ₹ 7132.57 on pruning and cutting (12.58\%) and ₹ 7011.43 on watch and ward $(12.37 \%)$, ₹ 5485.86 on manures and fertilizers (9.68\%) respectively in Kinnow cultivation (Table 3 ).

\section{Costs and returns from Kinnow orchard in Haryana}

Cost and returns from Kinnow orchard are presented in Table 4. Per hectare cost and return from Kinnow orchard from the year of establishment to the potential year of fruiting ( $7^{\text {th }}$ year). For the first 3 years there is lean 
period and production is near to negligible. Thereafter the production started increasing like 43 quintals in the $4^{\text {th }}$ year, 79 quintals in the $5^{\text {th }}$ year, 207 quintals in the $6^{\text {th }}$ year and 311 quintals in the $7^{\text {th }}$ year. However, after $7^{\text {th }}$ year of age the production remains static. So the gross returns per hectare increase up to $7^{\text {th }}$ year of orchard age. In the full bearing stage that is in the $7^{\text {th }}$ year, the gross returns were found to be ₹ 421405 per hectare which is expected to remain same up to 25 years of orchard life. The net returns from Kinnow orchard were calculated after taking into consideration various cost variable viz; rental value of the land, amortized fixed cost, operational cost of orchard, expected depreciation on fixed cost investment and interest on operational cost. After considering the returns from intercropping the net returns were found to be positive in the $6^{\text {th }}$ year (₹ 108817 per hectare). The net returns were estimated to increase to $₹ 257397$ in the $7^{\text {th }}$ years and after that it remain more or less same up to 25 years of orchard life. The net returns from Kinnow orchard up to $7^{\text {th }}$ year is presented in the figure 1.

\section{Economic feasibility of Kinnow orchard in Haryana}

To analyse the economic feasibility of Kinnow orchard four indicators like Net Present Value(NPV), Internal Rate of Returns(IRR), Benefit Cost (B:C) ratio, Payback period were computed which are discussed as below.

\section{Net present value of kinnow orchard in Haryana}

The data related to cost and returns in the table 4is not sufficient to act as a guiding tool in making decision to go for Kinnow orchard because the cost and returns from Kinnow orchard are obtained over times which are not compared with the cost and returns of annual crops. The data from the table 5 shows that the per hectare net present value of Kinnow orchard was found to be ₹ 747703.64 up to the age of 25 years which indicated that Kinnow orchard is highly profitable as the net present value is greater than zero and a higher positive value.

\section{Internal rate of return of Kinnow orchard in Haryana}

Internal rate of return is that discounting rate which makes the net present value zero or a minimum one. In the present study various discounting rates were taken to obtain the net present value zero or a minimum one. Finally, the internal rates of returns were found to be a higher value of 26.24 per annum. It means the Kinnow orchard is a highly profitable enterprise as the internal rate of return is higher than the prevailing interest rate that is 12 per cent per annum (Table 6).

\section{Benefit Cost ratio of Kinnow orchard in Haryana}

At the prevailing interest rate of 12 per cent the Benefit Cost ratio of Kinnow orchard were obtained 1:3.79. As this ratio is greater than one it implies that Kinnow orchard is a highly profitable enterprise. The Benefit cost ratio 1:3.79 means that at the prevailing interest rate of 12 per cent an investment of $₹ 1.00$ will fetch a return of ₹ 3.79 .

\section{Payback period of Kinnow orchard in Haryana}

From the table 4 it was clear that the net cost incurred during the first five years of orchard was ₹ 364673 per hectare. This cost was more than the net returns from the seventh year which was ₹ 366214 per hectare. This means the costs were recovered in the seventh year of establishment of Kinnow orchard. Hence the payback period of Kinnow orchard was found to be seven years. 
Table. 1 Trends in area, production and productivity of Kinnow in Haryana

\begin{tabular}{|c|c|c|c|}
\hline Years & Area ('000ha) & Production ('000T) & $\begin{array}{c}\text { Productivity } \\
\text { ( tonnes/ha) }\end{array}$ \\
\hline $\mathbf{2 0 0 5 - 0 6}$ & 5.04 & 69.56 & 13.80 \\
\hline $\mathbf{2 0 0 6 - 0 7}$ & 6.42 & 77.43 & 12.06 \\
\hline $\mathbf{2 0 0 7 - 0 8}$ & 8.21 & 66.84 & 8.14 \\
\hline $\mathbf{2 0 0 8 - 0 9}$ & 11.22 & 63.16 & 5.63 \\
\hline $\mathbf{2 0 0 9 - 1 0}$ & 13.84 & 98.33 & 7.11 \\
\hline $\mathbf{2 0 1 0 - 1 1}$ & 17.15 & 130.00 & 12.58 \\
\hline $\mathbf{2 0 1 2}-13$ & 17.66 & 214.17 & 11.99 \\
\hline $\mathbf{2 0 1 3 - 1 4}$ & 18.78 & 225.05 & 12.14 \\
\hline $\mathbf{2 0 1 4 - 1 5}$ & 19.38 & 235.35 & 15.49 \\
\hline $\mathbf{2 0 1 5 - 1 6}$ & 19.50 & 302.07 & 15.36 \\
\hline $\mathbf{2 0 1 6 - 1 7}$ & 19.65 & 301.76 & 16.15 \\
\hline $\mathbf{2 0 1 7 - 1 8}$ & 20.05 & 323.92 & 16.13 \\
\hline Average & 20.83 & 335.82 & 11.82 \\
\hline 2005-06 & 15.21 & 187.96 & 16.86 \\
\hline Percentage change over & 313.13 & 382.29 & \\
\hline (\%) p.a.) & $\mathbf{1 1 . 6 9}$ & $\mathbf{1 7 . 6 7}$ & $\mathbf{5 . 3 6}$ \\
\hline
\end{tabular}

(Source: Department of Horticulture, Govt. of Haryana)

Table.2 Establishment cost of Kinnow orchard in Haryana

\begin{tabular}{|c|l|c|c|}
\hline Sr. No. & Particulars & Value $(\mathbf{(}) /$ hectare) & Percentage \\
\hline $\mathbf{1}$ & Preparation of land and lay out & 6987 & 5.71 \\
\hline $\mathbf{2}$ & Digging and filling of pits & 5343 & 4.36 \\
\hline $\mathbf{3}$ & Cost of irrigation & 1051 & 0.86 \\
\hline $\mathbf{4}$ & Cost of plant & 6358 & 5.19 \\
\hline $\mathbf{5}$ & Cost of replacement plant & 965 & 0.79 \\
\hline $\mathbf{6}$ & Manures and fertilizer & 4737 & 3.87 \\
\hline $\mathbf{7}$ & Transportation of plant & 4659 & 3.80 \\
\hline $\mathbf{8}$ & Plantation cost & 2963 & 2.42 \\
\hline $\mathbf{9}$ & Intercultural operation & 1469 & 1.20 \\
\hline $\mathbf{1 0}$ & Construction of pond & 43578 & 35.59 \\
\hline $\mathbf{1 1}$ & Drip irrigation & 23546 & 19.23 \\
\hline $\mathbf{1 2}$ & Permanent fencing & 12543 & 10.24 \\
\hline $\mathbf{1 3}$ & Cost of equipment & 5874 & 4.80 \\
\hline $\mathbf{1 4}$ & Miscellaneous & 2387 & 1.95 \\
\hline & Total & 122460 & 100.00 \\
\hline
\end{tabular}


Table.3 Operational cost of Kinnow orchard in Haryana Value (₹/hectare)

\begin{tabular}{|c|c|c|c|c|c|c|c|c|c|c|c|}
\hline \multirow{2}{*}{$\begin{array}{l}\text { Sr. } \\
\text { No. }\end{array}$} & \multirow[t]{2}{*}{ Particulars } & \multicolumn{7}{|c|}{ Years } & \multirow{2}{*}{$\begin{array}{l}\text { Total } \\
\text { Cost }\end{array}$} & \multirow{2}{*}{$\begin{array}{c}\text { Average } \\
\text { cost } \\
\text { per Annum }\end{array}$} & \multirow[t]{2}{*}{ Percentage } \\
\hline & & $\mathbf{1}$ & 2 & 3 & 4 & 5 & 6 & $\begin{array}{c}7^{\text {th }} \text { and } \\
\text { onwards }\end{array}$ & & & \\
\hline 1 & Manure and fertilizer & 3127 & 3758 & 4523 & 5568 & 6894 & 7164 & 7367 & 38401 & 5485.86 & 9.68 \\
\hline 2 & $\begin{array}{l}\text { Plant protection insecticides, } \\
\text { pesticides }\end{array}$ & 8756 & 11503 & 12654 & 13569 & 14568 & 15102 & 15489 & 91641 & 13091.57 & 23.10 \\
\hline 3 & Pruning and cutting & & 3781 & 6873 & 9245 & 9741 & 9964 & 10324 & 49928 & 7132.57 & 12.58 \\
\hline 4 & Intercultural and hoeing & 4847 & 5468 & 6631 & 7863 & 8521 & 9253 & 9352 & 51935 & 7419.29 & 13.09 \\
\hline 5 & Irrigation cost & 4498 & 5120 & 5961 & 7546 & 8276 & 8791 & 8967 & 49159 & 7022.71 & 12.39 \\
\hline 6 & Replacement and casualty & 1437 & 1654 & 2145 & 2754 & 3124 & 3396 & 3758 & 18268 & 2609.71 & 4.60 \\
\hline 7 & Watch and ward & 4987 & 5489 & 6124 & 6717 & 7813 & 8703 & 9247 & 49080 & 7011.43 & 12.37 \\
\hline 8 & Staking & 0 & 0 & 0 & 7500 & 7800 & 8192 & 8175 & 31667 & 4523.86 & 7.98 \\
\hline \multirow[t]{2}{*}{9} & Miscellaneous & 1724 & 1923 & 2149 & 2465 & 2563 & 2785 & 2946 & 16555 & 2365.00 & 4.17 \\
\hline & Total operational cost & 29376 & 38696 & 47060 & 63227 & 69300 & 73350 & 75625 & 396634 & 56662.00 & 100 \\
\hline
\end{tabular}


Table.4 Costs and returns from Kinnow orchard in Haryana Value (₹ / hectare)

\begin{tabular}{|c|c|c|c|c|c|c|c|c|}
\hline \multirow{2}{*}{$\begin{array}{l}\text { Sr. } \\
\text { No. }\end{array}$} & \multirow[t]{2}{*}{ Particulars } & \multicolumn{7}{|c|}{ Years } \\
\hline & & $\mathbf{1}$ & 2 & 3 & 4 & 5 & 6 & $7^{\text {th }}$ and onwards \\
\hline 1 & Rental value of land & 44256 & 47234 & 48563 & 49671 & 52874 & 55963 & 58796 \\
\hline 2 & Amortized fixed cost & 15614 & 15614 & 15614 & 15614 & 15614 & 15614 & 15614 \\
\hline 3 & Operational cost & 29376 & 38696 & 47060 & 63227 & 69300 & 73350 & 75625 \\
\hline 4 & Expected depreciation on Fixed Cost investment @4\% & 4898 & 4898 & 4898 & 4898 & 4898 & 4898 & 4898 \\
\hline 5 & Interest on operational cost @ $12 \%$ PA & 3525 & 4644 & 5647 & 7587 & 8316 & 8802 & 9075 \\
\hline 6 & Total Cost $(1-5)$ & 97670 & 111086 & 121782 & 140997 & 151002 & 158627 & 164008 \\
\hline 7 & Production (qtls) & 0 & 0 & 0 & 43 & 79 & 207 & 311 \\
\hline 8 & Price (₹) per qtls & 0 & 0 & 0 & 1043 & 1148 & 1292 & 1355 \\
\hline 9 & Gross returns & 0 & 0 & 0 & 44849 & 90692 & 267444 & 421405 \\
\hline 10 & Net returns & 97670 & -111086 & -121782 & -96148 & -60310 & 108817 & 257397 \\
\hline \multirow[t]{2}{*}{11} & Return from inter cropping & 28974 & 25463 & 24151 & 24080 & 19654 & 0 & 0 \\
\hline & Total net returns & -68696 & -85623 & -97631 & -72068 & -40656 & 108817 & 257397 \\
\hline
\end{tabular}


Table.5 Net Present Value of Kinnow orchard in Haryana

\begin{tabular}{|c|c|c|c|c|c|}
\hline \multirow[t]{2}{*}{ Year } & \multirow{2}{*}{$\begin{array}{l}\text { Negative } \\
\text { returns } \\
(₹)\end{array}$} & \multirow{2}{*}{$\begin{array}{l}\text { Positive } \\
\text { returns } \\
(₹)\end{array}$} & \multirow{2}{*}{$\begin{array}{c}\text { Discounting } \\
\text { factor } 1 /(1+\mathrm{i})^{\mathrm{n}}\end{array}$} & \multicolumn{2}{|c|}{ Present value } \\
\hline & & & & $\begin{array}{l}\text { Negative } \\
\text { returns (₹) }\end{array}$ & $\begin{array}{c}\text { Positive } \\
\text { Returns (₹) }\end{array}$ \\
\hline 1 & 68696 & & 0.8929 & 61335.29 & \\
\hline 2 & 85623 & & 0.7972 & 68257.75 & \\
\hline 3 & 97631 & & 0.7118 & 69491.96 & \\
\hline 4 & 72068 & & 0.6355 & 45800.52 & \\
\hline 5 & 40656 & & 0.5674 & 23069.31 & \\
\hline 6 & & 108817 & 0.5066 & & 55130.08 \\
\hline 7 to 25 & & 257397 & 3.7317 & & 960528.38 \\
\hline Total & 364673 & 366214 & & 267954.82 & 1015658.46 \\
\hline
\end{tabular}

$\mathrm{NPV}=1015658.46-267954.82=747703.64$

Table.6 Internal rate of return of Kinnow orchard in Haryana

\begin{tabular}{|c|c|c|c|c|c|}
\hline Year & $\begin{array}{c}\text { Net cash } \\
\text { flow } \\
(₹)\end{array}$ & $\begin{array}{c}\text { Present Value } \\
\text { Coefficient } \\
r=26 \% \\
{\left[1 /(1+r)^{\mathbf{n}}\right]}\end{array}$ & $\begin{array}{l}\text { Corresponding } \\
\text { Value } \\
(₹)\end{array}$ & $\begin{array}{c}\text { Present Value } \\
\text { Coefficient } \\
r=27 \% \\
{\left[1 /(1+r)^{\mathbf{n}}\right]}\end{array}$ & $\begin{array}{c}\text { Corresponding } \\
\text { Value } \\
(₹)\end{array}$ \\
\hline 1 & -68696 & 0.7937 & -54520.25 & 0.8333 & -57246.27 \\
\hline 2 & -85623 & 0.6299 & -53932.05 & 0.6944 & -59460.08 \\
\hline 3 & -97631 & 0.4999 & -48806.42 & 0.5787 & -56499.54 \\
\hline 4 & -72068 & 0.3968 & -28593.04 & 0.4823 & -34755.02 \\
\hline 5 & -40656 & 0.3149 & -12801.83 & 0.4019 & -16338.73 \\
\hline 6 & 108817 & 0.2499 & 27194.02 & 0.3349 & 36442.59 \\
\hline 7 to 25 & 257397 & 0.9493 & 244346.97 & 1.6221 & 417523.67 \\
\hline Total & & & 72887.41 & & 229666.63 \\
\hline
\end{tabular}

IRR $=26+1(72887.41) /(72887.41+229666.63)=26.24$

Table.7 Constraints faced by Kinnow growers in Sirsa district of Haryana

\begin{tabular}{|l|c|c|c|}
\hline Constraints & $\begin{array}{c}\text { Total } \\
\text { score }\end{array}$ & $\begin{array}{c}\text { Average } \\
\text { score }\end{array}$ & Rank \\
\hline Lack of provision of infrastructure like processing and storage & 1844 & 61.47 & 1 \\
\hline Lack of availability of good quality planting material & 1830 & 61.00 & 2 \\
\hline Lack of assistance for protected cultivation for nursery & 1709 & 56.97 & 3 \\
\hline Lack of assistance for integrated post-harvest management & 1700 & 56.67 & 4 \\
\hline Inadequate assistance for creation of water resources & 1519 & 50.63 & 5 \\
\hline Inadequate facility for rejuvenation with improved cultivars & 1434 & 47.80 & 6 \\
\hline Lack of assistance for organic farming & 1390 & 46.33 & 7 \\
\hline Inadequate scope for horticulture mechanization & 1323 & 44.10 & 8 \\
\hline Poor marketing facility & 1222 & 40.73 & 9 \\
\hline Lack of promotion of INM and IPM & 1029 & 34.30 & 10 \\
\hline
\end{tabular}


Fig.1 Net returns from Kinnow orchard in Haryana

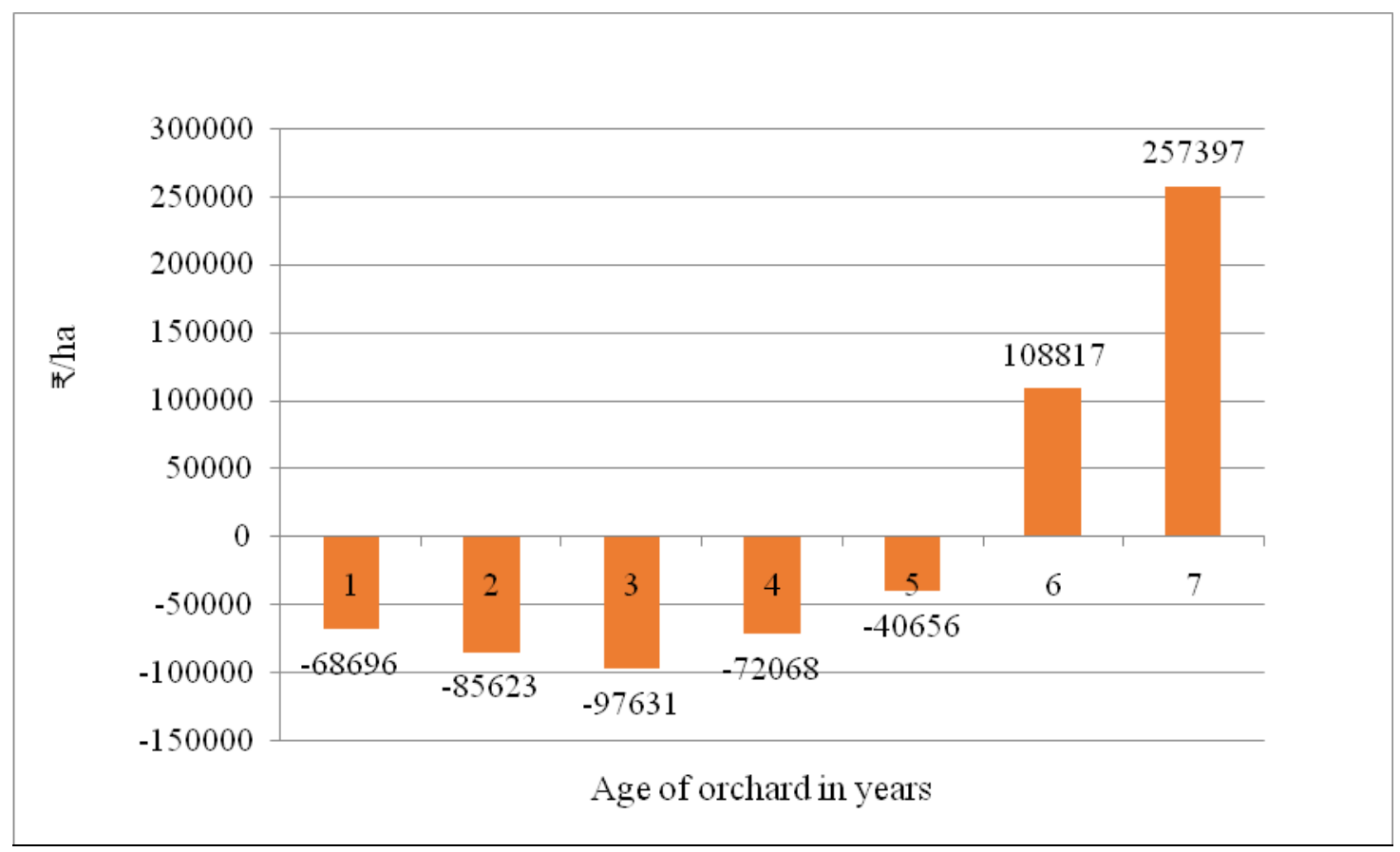

\section{Constraints faced by the Kinnow growers}

The response of farmers for various constraints encountered in cultivation of Kinnow were analysed through Garrett ranking technique. Majority of Kinnow growers in Sirsa district of Haryana expressed Lack of provision of infrastructure like processing and storage as major constraint followed by lack of availability of good quality planting material, lack of assistance for protected cultivation for nursery, integrated post-harvest management and inadequate assistance for creation of water resources. Other major constraints identified are inadequate facility for rejuvenation with improved cultivars, inadequate scope for horticulture mechanization, poor marketing facility and lack of promotion of INM and IPM (Table 7).

Conclusions and Policy implications are as follows:

The per hectare establishment cost of Kinnow orchard was found to be ₹ 122460. The average operational cost in the current year was found to be ₹ 75625. The payback period, B:C ratio, NPV, IRR were found to be 7years, $1: 3.79, \quad 26.24 \%$ and ₹ 747703.64 respectively. Some major constraints which inhibiting the Kinnow cultivation were identified as lack of infrastructure for processing, storage, lack of better marketing facility, post-harvest management etc. Keeping in view the high profitability and constraints, it can be suggested to the government to focus more on infrastructural facilities for post-harvest management, ensure availability of quality planting materials to the farmers and provide better marketing facility in the study so that more income of the farmers' can be ensured.

\section{References}

Bhat, A., Kachroo, J. and Kachroo, D.(2011) Economic appraisal of kinnow Production and its marketing under North- Western Himalayan Region of 
Jammu. Agricultural Economics Research Review, 24(2): 283-290.

Gangwar, L. S. and Singh, S. (1998). Economic evaluation of Nagpur mandarin cultivation in Vidarbha region of Maharashtra. Indian Journal of Agricultural Economics, 53(4): 648653.

Grover, D.K., Singh, J.M., Singh, J., and Kumar, S. 2012. Impact of emerging marketing channels in agriculturebenefit to producer-seller and marketing cost and margins of potato and kinnow in Punjab. AERC Study No.28, Punjab Agricultural University, Ludhiana: 1120.
Kumar, N. Duhan, A., Bhatia, J. and Malik, V. (2018). Economic appraisal of kinnow production and its marketing in Sirsa District of Haryana, India. International Journal of Current Microbiology and Applied Sciences, 6(11): 4045-4053.

Sharma, S., Singh, B., Rani, G., Zaidi, A. A., Hallan, V., Nagpal, A. and Virk, G. S. (2007). Production of Indian citrus ringspot virus free plants of kinnow employing chemotherapy coupled with shoot tip grafting. Journal of Central European Agriculture, 8(1): 1-8.

\section{How to cite this article:}

Mousumi Priyadarshini, K.K. Kundu, Dalip Kumar Bishnoi and Nirmal Kumar. 2020. An Economic Analysis of Kinnow Cultivation in Sirsa District of Haryana. Int.J.Curr.Microbiol.App.Sci. 9(07): 2341-2351. doi: https://doi.org/10.20546/ijcmas.2020.907.273 